\title{
Economic development of the construction industry as a basis for sustainable development of the country
}

\author{
Alfira Khaertdinova ${ }^{1 *[0000-0002-4556-7081]}$, Anna Maliashova ${ }^{10000-0003-4434-9258]}$, and Svetlana \\ Gadelshina $^{1}$ [0000-0002-8502-3740] \\ ${ }^{1}$ Kazan National Research Technological University, 420015, K. Marks st., Kazan, Russia
}

\begin{abstract}
This article examines the main trends in the construction industry as one of the most important economic sectors. Construction makes a significant contribution to the economic potential of the country it forms tangible assets and is an integral part of the wealth of the nation. We examined the resulting indicators of the industry in conjunction with macroeconomic indicators. The studies were carried out using statistics from the World Bank, the countries of the European Union and the Russian Federation in the period from 2000 to 2020 . The study set out to compare the indicators affecting construction activities, investment, incomes and other sectors. In parallel we looked at the factors affecting the volume of completed construction works by means of correlation analysis to identify symbiotic relationships between the selected data. The main goal of the study is to identify the factors affecting the performance of the industry and confirm by use of quantitative analysis.
\end{abstract}

Keywords: economic development, sustainable development, construction development, construction industry, housing construction, correlation analysis.

\section{Introduction}

Construction is one of the most important sectors of the economy, which creates jobs in the commissioning of new, repurposing of existing buildings and refurbishment projects for the entire national economy. Real estate created in construction is an integral part of the country's national wealth as nonfinancial production assets. Fixed assets in the structure of non-financial industrial assets form a significant share. Therefore, the fact that real estate created the construction industry in the form of fixed assets is the key to successful development of industries producing goods and services [1]. Fixed assets contribute to an increase in the national wealth of the country in the form of the accumulation of fixed capital. In this regard, the development of «construction» activity is of great importance for the development of the economy $[2,3]$. The construction industry occupies a fundamental role in the economy of any country, including Russia.

\footnotetext{
* Corresponding author: alfira_gks@mail.ru
} 
The economic situation and prospects for the development of the country's economy largely depend on investment activities. Investment activity has always been a necessary condition and source of economic growth [4]. Economic growth, in turn, is accompanied by the filling of the state budget, an increase in the profit of economic entities and, as a consequence, an increase in the income of the population. The increase in the income of the population affects the demand on all areas of the economy. High investment activity is what all developing and developed countries strive for. According to the World Bank [5], investment growth in the world has slowed sharply since mid-2007. The global financial crisis has brought this decline to $-8.9 \%$. By 2010, the investment climate improved, but did not reach its pre-crisis value, which remains the case.

The decrease in activity, as can be seen from the data in Table 1, was most pronounced among large countries: USA, Germany, United Kingdom, Russia, Canada, and China. In countries with emerging and developing markets, investment growth also slowed down not only under the influence of the global recession, but also as a consequence of slow economic development of these countries.

Table 1. Annual growth of gross fixed capital formation by countries for $2008-2019$, $\%$ to the previous period [5].

\begin{tabular}{|l|c|c|c|c|c|c|c|c|c|c|c|}
\hline & 2009 & 2010 & 2011 & 2012 & 2013 & 2014 & 2015 & 2016 & 2017 & 2018 & 2019 \\
\hline Germany & -9.45 & 5.27 & 7.38 & -0.22 & -1.27 & 3.24 & 1.74 & 3.8 & 2.5 & 3.52 & 2.51 \\
\hline $\begin{array}{l}\text { Great } \\
\text { Britain }\end{array}$ & -12.4 & 3.55 & -1.06 & 1.9 & 3.46 & 6.59 & 3.68 & 3.64 & 1.63 & -0.2 & 0.65 \\
\hline France & -9.0 & 2.08 & 2.06 & 0.23 & -0.8 & 0.03 & 1.02 & 2.66 & 4.74 & 3.2 & 4.23 \\
\hline Japan & -9.7 & -1.6 & 1.65 & 6.54 & 4.93 & 3.05 & 1.64 & -0.3 & 2.95 & 0.58 & - \\
\hline USA & -12.5 & 2.28 & 4.57 & 6.87 & 3.57 & 5.13 & 3.65 & 1.83 & 3.54 & 4.79 & 2.26 \\
\hline Russia & -14.4 & 5.9 & 9.09 & 6.19 & 1.91 & -2.2 & -10.6 & 1.26 & 4.65 & 0.19 & 1.47 \\
\hline Canada & -11.3 & 11.51 & 4.63 & 4.88 & 1.45 & 2.25 & -5.2 & -4.6 & 3.57 & 1.20 & -0.43 \\
\hline
\end{tabular}

In the post-crisis period, there has been a weak and uneven growth in investment in almost all countries, which does not contribute to an increase in sustainable economic development. In this case, it is advisable to form financial reserves and contain possible risks of financial instability.

Social and political conflicts that arise from time to time do not contribute to the growth of investment. Reduced trade, economic sanctions, protectionist policies lead to a reduction in the exchange of technological innovations and narrows investment activity with the ensuing consequences for changes in the accumulation of fixed capital.

Global trends in investment dynamics are also characteristic of the countries of the European Union [6]. In the countries of the Old World, construction plays an essential role in the development of the economies of countries. The industry's share is on average $5 \%-6$ $\%$ of GDP, and is one of the five largest sectors of the economy, which is comparable with similar values in Russia.

Figure 1 shows the dynamics of change in the volume of investments and production in construction, (in \% by 2015) in the countries of the European Union [7]. As can be seen from the graph (Fig. 1), there is a direct relationship between investment and production in construction. Decrease in production in construction in 2011-2015 was replaced by their gradual growth in subsequent years. Over the past five years, production in construction has grown on average by $2.5 \%-2.6 \%$. A slight recovery is not linked to economic growth in construction (Table 2) [7]. However, the financial reserves of these countries made it possible to increase the volume of savings, reduce public debt and reduce the negative budget balance.

The rise in the inflation rate, which is so unusual for the EU countries, indicates that in recent years the fiscal policy in the EU countries has been aimed at the formation of 
financial reserves, so it is necessary to increase investments in order to increase sustainable development [8], including the development of construction.

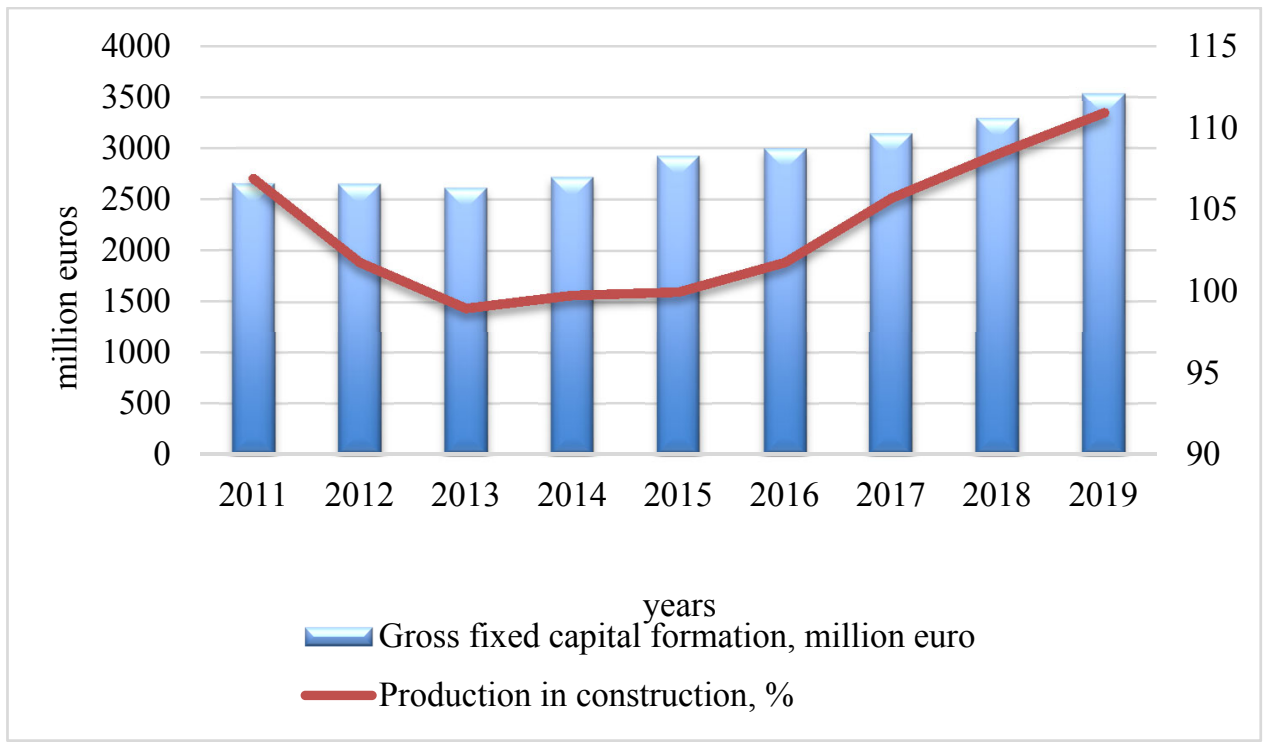

Fig. 1. Dynamics of gross fixed capital formation (million euros) and production in construction (\%) in the European Union for 2009-2019 [7].

Table 2. Macroeconomic indicators of the European Union for 2015-2019, \% [7].

\begin{tabular}{|l|c|c|c|c|c|}
\hline & 2015 & 2016 & 2017 & 2018 & 2019 \\
\hline Real GDP, \% to the previous year & 2.5 & 2.1 & 2.8 & 2.2 & 1.5 \\
\hline $\begin{array}{l}\text { The volume of completed } \\
\text { construction and installation work }\end{array}$ & -2.3 & 1.8 & 3.8 & 2.5 & 2.3 \\
\hline Accumulation rate, \% of GDP & 20.2 & 20.5 & 20.9 & 21.2 & 21.2 \\
\hline Average annual inflation, \% & 0.1 & 0.2 & 1.7 & 1.9 & 1.5 \\
\hline Population, million people & 507.2 & 508.5 & 509.5 & 510.4 & 511.3 \\
\hline State budget balance, \% of GDP & -2.3 & -1.6 & -1.0 & -0.6 & -0.9 \\
\hline Public debt, \% of GDP & 71.3 & 70.6 & 68.5 & 67.0 & 66.9 \\
\hline
\end{tabular}

In a sector that has been developing slowly over decades using the same technologies, the need for innovation is increasing [9, 10]. Growing industrialization is driving developers to more innovative new building materials, often at the expense of the environment. European countries are heading towards sustainable construction, taking into account the principles of possible reuse of materials during deconstruction [11]. Disposal issues need to be addressed at the design stage by rethinking the entire value chain. Sustainable development presupposes a balance of three components: economy, ecology and social sphere $[12,13]$. The balanced coexistence of these components will make the transition from a linear economy to a circular one [14-16].

Russian construction industry for many years shows stable development, although structural changes and economic instability have appeared in the sector [17-19].

Since the 2000's, the Russian economy has seen an increase in production in all sectors. The main reason for economic growth can be considered an external factor - the growth of Russian exports against the background of a favourable situation in the world energy market [20]. Expansion of domestic demand and improvement of the financial position of the real estate sector of the country's economy also played a positive role. The volume of 
completed construction and installation works (CIW) throughout the entire period grew at an outstripping pace. This was facilitated by actively developing state construction projects: pipelines to eastern Siberia and Kamchatka, a gas pipeline to Petrozavodsk in 2000, the Eastern Siberia - Pacific Ocean pipeline in 2006, an oil refinery in Tyumen - 2004, an aluminium plant in the Irkutsk region - 2000, automobile factories, energy and hydropower construction, road construction and many other industrial and social facilities contributed to the active process of investment development. Housing construction was also actively developing, so from 2000 to 2010 the commissioning of residential premises doubled from 30.3 million $\mathrm{m}^{2}$ in 2000 to 59.9 million $\mathrm{m}^{2}$.

In 2009 compared to 2000 , the amount of investment in fixed assets in construction in nominal terms increased by almost four times. This supported an average annual growth in construction of $118 \%-113 \%$ per year in real terms. These indicators significantly exceeded the growth rates of other basic industries such as manufacturing, agriculture and trade.

For the first time in 20 years, the industry showed a decline in 2009 . The volume of CIW decreased even in nominal terms relative to the previous year ( -530 billion rubles), in real terms the decline was $-13.2 \%$. Business activity has declined as a result of the global financial crisis of 2009. The volume of investments in 2009 decreased by almost a third, from 400 billion rubles to 290 billion rubles, the number of employees also decreased by $2.8 \%[21]$.

However, our country was able to get out of the financial crisis rather quickly, thanks to the rise in oil prices (prices in 2010 did not fall below $\$ 80$ per barrel and provided $50 \%$ of all budget revenues of the country). The Stabilization Fund, created during the period of a «strong» economy in 2004 allowed the government to form a package of financial incentives for the recovery and development of the country's economy.

In the last decade, the dynamics in the development of the industry, as can be seen in Fig. 2, coincides with the general economic direction of the country's development.

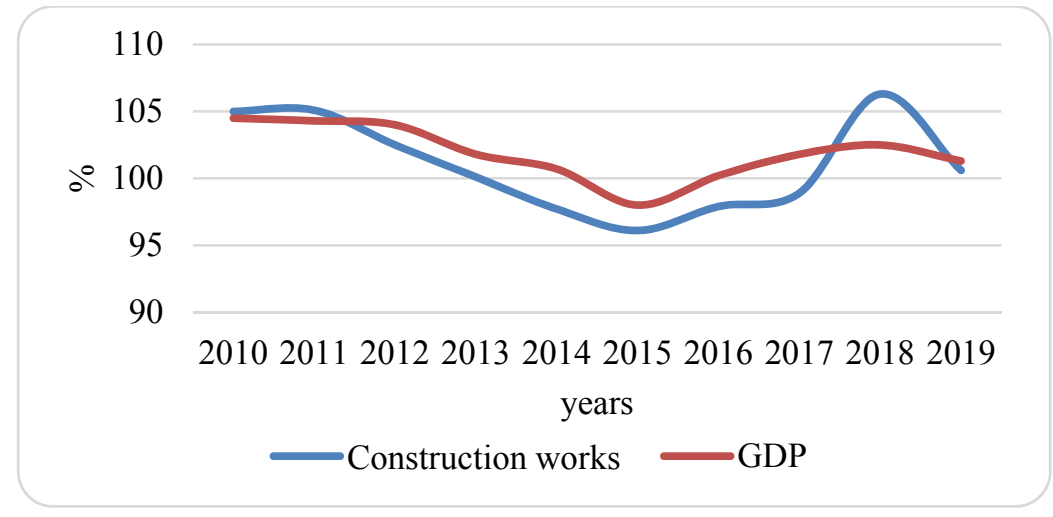

Fig. 2. Dynamics of changes in the growth rates (decrease) in the volume of construction and installation work and GDP [21,22].

The Construction industry in the structure of the produced gross domestic product occupies a significant share and does not undergo significant changes. As can be seen from Table 3, the share of value added in construction is at a level of $6 \%$. This indicates a stable contribution to the industry in the country's economic potential. A slight decrease $(0.3 \%$ $0.1 \%$ ) is explained by a decrease in the volume of work performed in 2014-2017. 
Table 3. The share of the type of activity «Construction» in Russia's GDP [21].

\begin{tabular}{|l|c|c|c|c|c|c|}
\hline & 2010 & 2015 & 2017 & 2018 & 2019 & 2020 \\
\hline in \% of GDP & 6.5 & 6.3 & 6.0 & 5.6 & 5.6 & 5.7 \\
\hline
\end{tabular}

The share of intermediate consumption is high in construction. This indicates the high importance of this type of activity for the development of other industries that are suppliers of products for construction work [23].

What caused such a long, albeit small, but still decrease in the volume of work performed as a percentage of the previous year, in the Construction industry i.e. decline expressed in real terms less inflationary processes? When analysing more disaggregated data, one can see that a downward trend is observed during 2014-2017. (48 months). Taking into account the fact that the economy is at a stage of stagnant decline, a similar situation in other industries was not present.

In construction, the number of operating organizations is steadily growing, with the main share being private property. The main volume of construction works also falls on private property. Since 2015, this share has exceeded $90 \%$ [22]. In the period from 2014 to 2017 , the number of newly registered enterprises increased by $23.2 \%$, of which private by $24.2 \%$, i.e. the private sector is growing at a faster pace, but the dynamics of production is downward. In order to understand the reason for such a decrease, one should understand the structure of construction work carried out by organizations of different forms of ownership. Civil and housing construction is mainly carried out by developers with the attraction of funds from equity participants in the construction industry. The second player - developer in housing - is the sector of individual housing construction.

Table 4. Investments in fixed assets for construction by private investors*.

\begin{tabular}{|l|c|c|c|c|c|c|}
\hline & 2010 & 2015 & 2016 & 2017 & 2018 & 2019 \\
\hline $\begin{array}{l}\text { Funds of organizations and the } \\
\text { population for shared } \\
\text { construction, billion rubles }\end{array}$ & 144.2 & 334.3 & 340.7 & 400.0 & 478.6 & 627.0 \\
\hline $\begin{array}{l}\text { In \% to the previous year of } \\
\text { them }\end{array}$ & $\mathrm{x}$ & 99.8 & 98.8 & 113.9 & 111.5 & 123.6 \\
\hline $\begin{array}{l}\text { Funds of the population, billion } \\
\text { rubles }\end{array}$ & 80.5 & 252.3 & 264.6 & 303.7 & 339.0 & 455.3 \\
\hline In \% to the previous year & $\mathrm{x}$ & 101.0 & 101.1 & 111.3 & 104.0 & 126.7 \\
\hline
\end{tabular}

* Authors' calculations

As can be seen from the data presented in Table 4, funds for housing are increasing at the expense of both sectors. The increase in private investment affects the rates of commissioning of residential buildings (Fig. 3) [22]. However, in real terms, 2015 and 2016 growth rates declined. This indicates a lack of funding, which could have affected the overall rate of decline in the industry. 


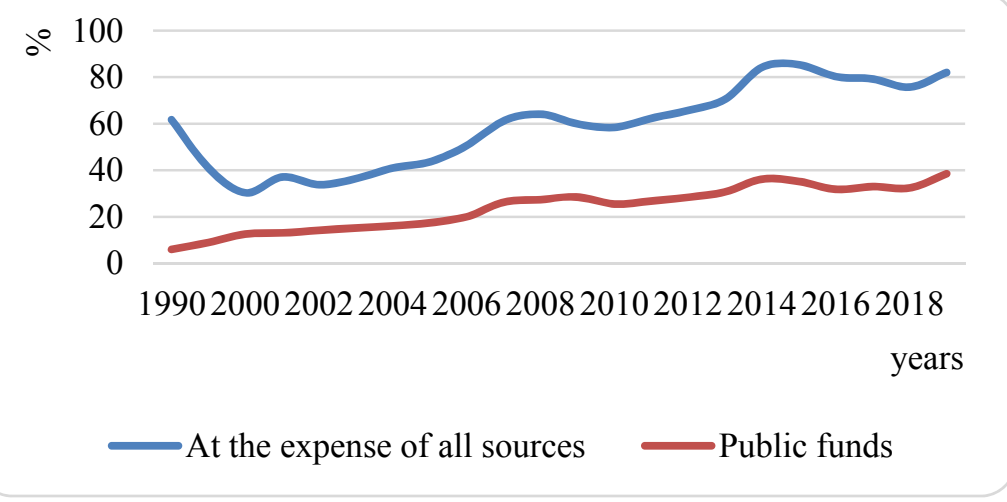

Fig. 3. Commissioning of residential buildings, mln.m 2 of the total area of residential premises [22].

Lack of financing, low effective demand by the population and lack of funds from developers during the construction phase can lead to a decrease in the implementation of CIW. Budget co-financing of housing construction is currently missing in almost all regions of the country and cannot promote the growth of the volume of work performed in the whole industry. The «Construction» activity refers to a process with a long production cycle. For its implementation, funds are needed already at the stage of construction start. Thus, the developer can be competitive only if it is the major player and has access to longterm loans. Private investors are not willing to take up the projects outside the city limits that require large investments and create additional infrastructure. The development of new sites is associated with additional costs and lengthens the investment period, which cannot lead to the accelerated development of the industry. In general, housing construction is coping with the task. Restraining the recession in housing construction was facilitated by the reduction of the key refinancing rate by the Central Bank of Russia and the decision of the Government of the Russian Federation to extend the program of subsidizing the mortgage rate for the purchase of housing in new buildings. Against the background of declining incomes of the population, this fact had a positive impact on the development of this direction in construction.

The construction of non-residential buildings: engineering structures, power lines, drilling of wells, laying of gas and oil pipelines and other types of industrial construction have other sources of funding, industrial construction is weaker than in civil construction. As you can see from the data presented in Table 5, the volume of work performed in certain areas has a negative trend.

Table 5. Dynamics of commissioning of objects of non-civil construction [22].

\begin{tabular}{|c|c|c|c|c|c|c|}
\hline & 2010 & 2015 & 2016 & 2017 & 2018 & 2019 \\
\hline Commissioning of structures & & & & & & \\
\hline $\begin{array}{c}\text { - power lines with a voltage } \\
\text { of } 35 \mathrm{kV} \text { and above, } \\
\text { thousand km }\end{array}$ & 2.1 & 2.3 & 2.7 & 1.8 & 2.4 & 2.8 \\
\hline $\begin{array}{c}\text { - automobile roads with } \\
\text { hard surface, thousand km }\end{array}$ & 3.1 & 2.5 & 2.5 & 2.3 & 2.3 & 2.9 \\
\hline - new railway lines, km & 111.1 & 17.8 & 62.5 & 157.0 & 30.4 & 96.2 \\
\hline $\begin{array}{c}\text { - main gas pipelines and } \\
\text { branches from them, } \\
\text { thousand km }\end{array}$ & 2.0 & 2.5 & 1.0 & 0.8 & 0.4 & 1.3 \\
\hline
\end{tabular}




\begin{tabular}{|c|c|c|c|c|c|c|}
\hline $\begin{array}{c}- \text { main oil pipelines and } \\
\text { regional oil pipelines, } \\
\text { thousand km }\end{array}$ & 1.2 & 0.8 & 0.9 & 0.3 & 0.5 & 0.7 \\
\hline $\begin{array}{c}\text { - Commissioning of social } \\
\text { and cultural facilities. }\end{array}$ & 22.9 & 143.3 & 63.3 & 40.8 & 49.9 & 105.4 \\
\hline $\begin{array}{c}\text { - preschool educational } \\
\text { institutions, thousand } \\
\text { places }\end{array}$ & 8.7 & 4.3 & 6.1 & 3.9 & 2.9 & 3.9 \\
\hline $\begin{array}{c}\text { - hospital organizations, } \\
\text { thousand beds }\end{array}$ & 26.8 & 23.7 & 18.1 & 20.7 & 24.5 & 21.3 \\
\hline $\begin{array}{c}\text { - outpatient clinical } \\
\text { organizations, thousand } \\
\text { visits per shift }\end{array}$ & & & & & \\
\hline
\end{tabular}

For the construction of social and cultural facilities, or structures of a strategic federal level, budget allocations are required, the use of centralized funds and reserves or the company's own funds. At a time when the country is in a phase of economic recession it is clear that the launch of government support programs largely becomes problematic. The increase in the key interest rate on loans by the Central Bank of Russia in 2014 led to the fact that access to «cheap» money stopped and this aggravated the situation in the construction market.

One evidence of the unstable situation in the building industry can serve as a decline in business activity in industries engaged in the production of building materials in the industry. So, according to the results of the analysis of the manufacturing industries, a decrease in the production of basic building materials was recorded in the period 20142017 , as a result of a decrease in demand. In particular, cement production over the years fell steadily at a rate of $90.3 \%$ in $2015,89.0 \%$ in $2016,99.5 \%$ in 2017 . Concrete production, respectively, $87.2 \%, 81.9 \%$ and $99.7 \%$., and Glass production - $93.9 \%, 98.1$ $\%$ and $111.2 \%$. A similar decline in the production of the main types of building materials has not been observed for many years.

In the first half of 2020, housing construction developed amid the (COVID-19) pandemic, which negatively affected both the global and Russian economies [24, 25]. Measures have been taken in many countries to restrict economic activity, including the suspension of construction activities starting in March 2020.

In connection with the situation in many countries, and some regions of Russia was carried out construction freeze. This had serious negative consequences in many areas of construction, including housing construction. According to the Federal State Statistics Service, in the first half of 2020, there was a decrease in housing commissioning by $5.5 \%$ compared to the same period of the previous year (Fig. 4) [26].

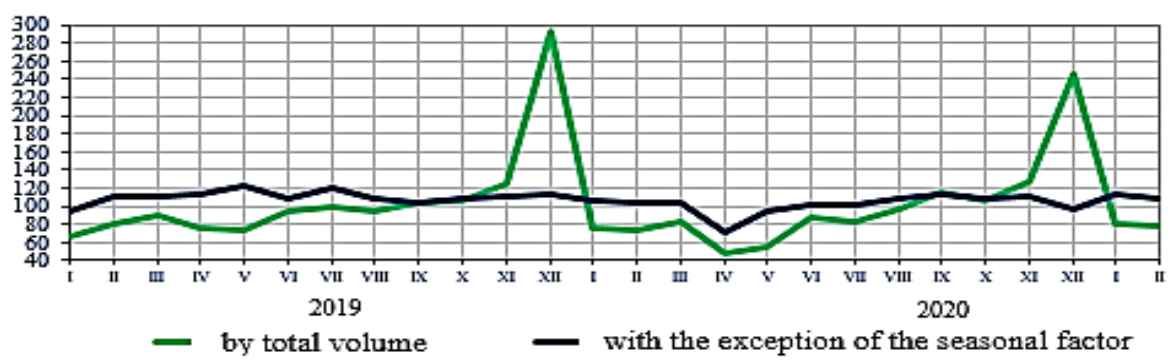

Fig. 4. Dynamics of commissioning of residential buildings in the Russian Federation in 2019-2021, in $\%$ to the average monthly value of 2018 [26]. 
In the second half of 2020, the pace of housing commissioning in Russia began to increase, which can be associated with the search for alternative ways of investment among the population against the backdrop of a fall in the exchange rate.

\section{Materials and methods}

To identify the relationship between the completed construction and installation work and the indicators of the country's economic growth, a statistical method of quantitative analysis of links was used, which allows using the correlation coefficient to determine the degree of dependence between the given economic indicators.

For the correlation analysis, the following data sample was selected:

- The volume of work performed by the Construction industry was chosen as the resulting indicator.

- The following indicators have been selected as factors influencing this resulting indicator: production of gross domestic product, investments in fixed assets, commissioning of residential buildings in the population at the expense of own and borrowed funds, the consolidated price index for investment products, the number of construction organizations, monetary incomes of the population and the consumer price index.

As a hypothesis, the results of this analytical study were put forward: the higher the level of development of the economy is, the more opportunities to invest in the economy and increase the accumulation of fixed capital exist, i.e. to increase the volume of produced tangible assets.

The studies were carried out according to Rosstat data using the dynamics for - 2000 2020 .

\section{Results and discussion}

Based on the data presented, a correlation analysis was carried out and correlation coefficients were obtained, showing the relationship between the volume of work performed by the type of activity «Construction» and a set of factors characterizing both the construction sector of the Russian economy and individual macroeconomic indicators.

The obtained correlation coefficients are presented in table 6 .

Table 6. Coefficients of correlation of individual indicators for the volume of CIW.

\begin{tabular}{|c|c|c|c|c|c|c|c|}
\hline & \multicolumn{7}{|c|}{ Factors affecting the resulting indicator } \\
\hline & $\begin{array}{l}\text { Fixed } \\
\text { capi- } \\
\text { tal in- } \\
\text { vest- } \\
\text { ment }\end{array}$ & $\begin{array}{l}\text { Commis- } \\
\text { sioning of } \\
\text { residential } \\
\text { buildings }\end{array}$ & $\begin{array}{l}\text { Conso- } \\
\text { lidated } \\
\text { price } \\
\text { index for } \\
\text { invest- } \\
\text { ment } \\
\text { products }\end{array}$ & $\begin{array}{l}\text { Number } \\
\text { of } \\
\text { construc- } \\
\text { tion } \\
\text { organi- } \\
\text { zations }\end{array}$ & $\begin{array}{l}\text { Mone- } \\
\text { tary } \\
\text { income } \\
\text { of the } \\
\text { popu- } \\
\text { lation }\end{array}$ & $\begin{array}{l}\text { Con- } \\
\text { sumer } \\
\text { price } \\
\text { index }\end{array}$ & GDP \\
\hline $\begin{array}{l}\text { The volume } \\
\text { of work } \\
\text { performed by } \\
\text { the type of } \\
\text { activity } \\
\text { «Construction» }\end{array}$ & 0.997 & 0.959 & -0.6207 & 0.973 & 0.9882 & -0.793 & 0.9908 \\
\hline
\end{tabular}

All correlation coefficients have values greater than 0.5 in absolute value, which indicates the presence of a stable relationship between the selected factors and the resulting indicator. 
The lowest correlation is observed between the volumes of construction and commissioning of residential houses of the Russian population at the expense of own and borrowed funds. This ratio was the smallest value of 0.9590 . Nevertheless, we can say that an increase in the population's demand for residential construction causes an increase in the volume of construction work.

Investments in fixed assets, the number of operating construction organizations, cash incomes of the population are directly related to the volume of construction work, the correlation coefficients were $0.9972,0.9730,0.9882$, respectively. The higher the volume of investments in fixed assets, the greater the number of operating construction organizations and the higher the monetary income of the population, the higher the volume of construction work performed.

The relationship between the volume of GDP produced and the volume of work performed is close and direct, the correlation coefficient was 0.9908 , which confirms the hypothesis under study: an increase in the volume of construction work performed is affected by the growth in the volume of GDP produced.

The indicators of the consolidated price index for investment products and the consumer price index have an inverse relationship with the volume of construction work. However, since the values of the correlation coefficients are greater than 0.5 in modulus, it can be argued that the increase in prices in construction and in the economy as a whole has a negative effect on the output of construction products.

\section{Conclusions}

Summing up the above, we can conclude that the revival of the construction industry in Russia depends on many factors, and primarily on general changes in the economy as a whole. Stabilization of the general economic situation will make it possible to bring the federal and regional budgets of the regions into line when a situation arises that budget sequestration can be avoided or at least not reduced capital investments for industrial construction, construction of cultural and social facilities.

The stabilization of the economy will lead to an increase in real disposable income of the population that will facilitate the transition of people with a category of pent-up demand for the purchase of durable goods, including the purchase of housing. Obviously, developers have a great interest from domestic demand and from the speedy sale of their products.

The correlation analysis showed the relationship between the growth in the volume of construction and installation work and certain macroeconomic and industry indicators. The calculated correlation coefficients revealed a significant relationship between all these factors. Found that the greatest impact on the volume of construction works have a fixed investment, GDP, household income, the number of construction organizations.

\section{Acknowledgements}

The team of authors is grateful for the advice of Andrew Manning. Andrew Manning has provided his technological expertise to track major economic trends in construction.

Andrew Manning, Managing Director Opura Projects Member of:

- Royal Institute of Chartered Surveyors.

- Chartered Institute of Bilding.

- Association of Project Management (https://opuraprojects.com). 


\section{References}

1. L. Ustinova, R. Sirazetdinov, Factors affecting the parameters of the construction industry, IOP Conference Series: Materials Science and Engineering, 890, 1, 0121172020 (2020) DOI: 10.1088/1757-899X/890/1/012117

2. B. Liu, L. Zhang, J. Sun, D. Wang, C. Liu, M. Luther, Y. Xu, Analysis and comparison of embodied energies in gross exports of the construction sector by means of their value-added origins, Energy, 191, 116546 (2020) DOI: 10.1016/j.energy.2019.116546

3. H.M. Barber Jr, I.H. El-Adaway. Economic performance assessment for the construction industry in the southeastern United States, Journal of Management in Engineering, 31, 2 (2015) DOI: 10.1061/(ASCE)ME.1943-5479.0000272

4. O.O. Tomilin, V.V. Gryschko, S.A. Kolomiyets, Features of Investment Regulation of Construction in Agriculture, Lecture Notes in Civil Engineering, 73, 741-755 (2020) DOI: 10.1007/978-3-030-42939-3_73

5. The world bank: [electronic resource]. URL: https://data.worldbank.org/indicator/NE.GDI.FTOT.KD.ZG (Last accessed: 01.04.2021)

6. K.C.V. Schönfeld, A. Ferreira, Urban planning and european innovation policy: Achieving sustainability, social inclusion, and economic growth? Sustainability, 13, 3, 1137, 1-35 (2021) DOI: 10.3390/su13031137

7. Eurostat: [electronic resource]. URL: https://ec.europa.eu/eurostat. (Last accessed: 01.04.2021)

8. A. Saieed, R. Luken, X. Zheng, Tracking progress in meeting sustainable development goal 9 industry-related targets: An index for policy prioritization, Applied Energy, 286, $116490(2021)$

9. M. Marčeta, S. Bojnec, Innovation and competitiveness in the European Union countries, International Journal of Sustainable Economy, 13, 1, 1-17 (2021) DOI: 10.1504/IJSE.2021.113316.

10. Q. Yang, X. Hu., Y. Wang, Y. Liu, J. Liu, J. Ma, X. Wang, Y. Wan, J. Hu, Z. Zhang, X. Wang, S. Tao, Comparison of the impact of China's railway investment and road investment on the economy and air pollution emissions, Journal of Cleaner Production, 293, 126610 (2021) DOI: 10.1016/j.jclepro.2021.126100.

11. F. Kedir, D. M. Hall, Resource efficiency in industrialized housing construction - A systematic review of current performance and future opportunities, Journal of Cleaner Production, 286, 125443 (2021) DOI: 10.1016/j.jclepro.2020.125443

12. A. Khaertdinova, A. Maliashova, S. Gadelshina, How patents support the development of new technologies in waste management, E3S Web of Conferences, 247, 01011 (2021) DOI: $10.1051 / \mathrm{e} 3$ sconf $/ 202124701011$

13. A. Khaertdinova, D. Sultanova, A. Karimov, European waste management experience: yesterday, today, tomorrow, E3S Web of Conferences, 247, 01008 (2021) DOI: 10.1051/e3sconf $/ 202124701008$

14. D. Sultanova, A. Maliashova, S. Gadelshina, Waste management as an element of sustainable development of the circular economy in the European Union, E3S Web of Conferences, 247, 01007 (2021) DOI: 10.1051/e3sconf/202124701007

15. A. Khaertdinova, D. Sultanova, D. Iskhakova, A. Karimov, Recycling of Polymers - An Opportunity or a Threat to the Economy? E3S Web of Conferences: ICEPP 2020, 161, 01058 (2020) DOI: 10.1051/e3sconf/202016101058

16. D. Sultanova, A. Maliashova, L. Abzalilova, R. Sultanova, The main obstacles for development of international activity with russian-european chemical clusters: environmental aspect, E3S Web of Conferences: ICEPP 2020, 161, 01101 (2020) DOI: $10.1051 / \mathrm{e} 3$ sconf $/ 202016101101$ 
17. E. G. Russkova, I. V. Mitrofanova, O. Y. Vatyukova, N. P. Ivanov, V. V. Batmanova, Structural changes in the GDP Of Russia in 1995-2015: Sectoral approach, Regional and Sectoral Economic Studies, 17, 39-58 (2017)

18. A. Romanova, E. Mukharramova, Sh. Akhmetov. Identification of a crisis situation in the enterprises of the construction services market. INZHEKON Bulletin, Series: Economics. 6, 157-162 (2010)

19. A. Romanova, E. Dobroserdova, Investment development of the construction complex of the region on the basis of project financing, Izvestia KGASU,4, 459-464 (2012)

20. N. B. Kosareva, R. A. Popov, A. S. Puzanov, Economic performance of Russian regions' capital cities, Area Development and Policy (2020) DOI: 10.1080/23792949.2020.1830707

21. Federal State Statistics Service. Russia in numbers-2020: [electronic resource]. URL: https://gks.ru/bgd/regl/b20_11/Main.htm (Last accessed: 01.04.2021)

22. Federal State Statistics Service. Construction in Russia-2020: [electronic resource]. URL: https://gks.ru/bgd/regl/b20_46/Main.htm. (Last accessed: 01.04.2021)

23. P. T. Nguyen, Q. Le Hoang Thüy To Nguyen, Critical factors affecting construction price index: An integrated fuzzy logic and analytical hierarchy process, Journal of Asian Finance, Economics and Business, 7, 197-204 (2020) DOI: 10.13106/JAFEB.2020.VOL7.NO8.197

24. I. Oncioiu, M. A. Postole, G. C. Georgescu, R. Gherghina, R.-A. Grecu, Transforming the covid-19 threat into an opportunity: The pandemic as a stage to the sustainable economy, Sustainability, 13, 208, 1-19 (2021) DOI: 10.3390/su13042088

25. J. Cifuentes-Faura, Analysis of containment measures and economic policies arising from COVID-19 in the European Union, International Review of Applied Economics, 35, 242-255 (2021) DOI: 10.1080/02692171.2020.1864300

26. Federal State Statistics Service. Construction in Russia-2020: [electronic resource]. URL: https://rosstat.gov.ru/ (Last accessed: 01.04.2021) 